Chinese Science Bulletin 2006 Vol. 51 No. 16 1955-1960

DOI: 10.1007/s11434-006-2037-9

\section{Coagulation properties of an electrochemically prepared polyaluminum chloride containing active chlorine}

\author{
HU Chengzhi ${ }^{1,2}$, LIU Huijuan ${ }^{1}$ \& QU Jiuhui ${ }^{1}$
}

1. State Key Laboratory of Environmental Aquatic Chemistry, Research Center for Eco-Environmental Sciences, Chinese Academy of Sciences, Beijing 100085, China;

2. Graduate School of Chinese Academy of Sciences, Beijing 100039, China

Correspondence should be addressed to Qu Jiuhui (email: jhqu@ rcees.ac.cn)

Received December 5, 2005; accepted March 27, 2006

Abstract With high content of the $\mathrm{Al}_{13}$ species and the active chloride, an electrochemically prepared polyaluminum chloride (E-PACl) presents integrated efficiency of coagulation and oxidation. The coagulation properties of E-PACl were systemically investigated through jar tests in the various water quality conditions. The active chlorine in E-PACl can significantly influence the coagulation behavior due to the active chlorine preoxidation, which can change the surface charge characteristic of organic matter (OM) in water. The active chlorine preoxidation could improve the E-PACl coagulation efficiency if the water possessed the characteristics of relatively low OM content $(2 \mathrm{mg} / \mathrm{L})$ and high hardness $(278 \mathrm{mg}$ $\left.\mathrm{CaCO}_{3} / \mathrm{L}\right)$. In the water with medium content of OM (5 $\mathrm{mg} / \mathrm{L})$, dosage would be a crucial factor to decide whether the active chlorine in E-PACl aided coagulation process or not. Comparing with alkaline condition, active chlorine would show a more significant influence on the coagulation process in acidic region.

Keywords: flocculation, preoxidation, disinfection, $\mathrm{Al}_{13}$ species, water treatment.

Polyaluminum chloride ( $\mathrm{PACl})$ is widely used in water treatment process. Comparing with the traditional $\mathrm{Al}$ coagulants such as alum and $\mathrm{AlCl}_{3}, \mathrm{PACl}$ can remove particles and organic matter $(\mathrm{OM})$ with inherent advantages of less alkalinity consumption, lower cost, less sludge production, less temperature dependence, and less $\mathrm{pH}$ dependent ${ }^{[1-4]}$. It is known that $\mathrm{PACl}$ products contain cationic species, of which the most important one is $\mathrm{Al}_{13}\left(\left[\mathrm{AlO}_{4} \mathrm{Al}_{12}(\mathrm{OH})_{24}\left(\mathrm{H}_{2} \mathrm{O}\right)_{12}\right]^{7+}\right)$ species $^{[5-7]}$. Besides the characteristics of high positive charge and strong binding ability to aggregates, it is temporarily refractory to hydrolysis before adsorption onto particle surfaces. These special properties contribute to the superior behavior of $\mathrm{PACl}$ in coagulation. Many researchers believed that the $\mathrm{Al}_{13}$ was the most active species in $\mathrm{PACl}$ composition responsible for coagulation or precipitation ${ }^{[8,9]}$. Thus they claimed that high content of $\mathrm{Al}_{13}$ was the main aim of the research and production technology of $\mathrm{PACl}^{[10,11]}$.

It has been confirmed that the electrolysis process could produce effective $\mathrm{PACl}{ }^{[12-15]}$. Besides the high $\mathrm{Al}_{13}$ content in production, the method was suitable for preparation on the spot and dosing immediately. However, high producing cost is a disadvantage for the wide application of this method to synthesizing PACl. Besides the charge of electricity, the consumption of $\mathrm{Al}$ sheet, which is the major source of $\mathrm{Al}$ content in the preparation of $\mathrm{PACl}$, accounts for about $60 \%$ of the producing cost. Recently, the technique was successfully improved ${ }^{[16]}$. E-PACl with a relative low producing cost can be prepared by dimensional stable anode (DSA). The new technique still endowed production with high $\mathrm{Al}_{13}$ content. Furthermore, the electrochemically prepared $\mathrm{PACl}$ (E-PACl) also contained high content of active chlorine. E-PACl presented the integrated properties of coagulation with disinfection. When dosed into water, E-PACl simultaneously combines together two distinct and separate functions (viz. chemical coagulation and disinfection) and thus can potentially be used as a dual-function chemical reagent for water treatment. This may offer significant advantages in practice since a single dosing and mixing unit is required when using E-PACl, the capital and running costs are expected to be cheaper and less management is required, in comparison with the conventional two-unit system using coagulant and disinfectant.

In water treatment plants, active chlorine is widely used in preoxidation and disinfection process. Besides decoloration, deodorization, and inactivating microorganisms, preoxidation can remove some inorganic matter ${ }^{[17,18]}$, increase the biodegradability of $\mathrm{OM}^{[19,20]}$, and reduce the trihalomethane formation potential ${ }^{[21]}$. However, there were many conflicting results about whether preoxidation could aid the coagulation process or not. For example, Richard et al. ${ }^{[22,23]}$ and Jekel ${ }^{[24]}$ found that preoxidation could improve coagulation efficiency, but the results of Reckhow and Singer ${ }^{[25]}$ and Mathonnet 


\section{ARTICLES}

et $a l .{ }^{[26]}$ indicated that preoxidation retarded coagulation. Moreover, Farvardin and Collins ${ }^{[27]}$ and Beker and $\mathrm{O}^{\prime} \mathrm{Melia}^{[28]}$ argued that the dosage of preoxidants was a key factor to determine whether preoxidation could aid or retard the coagulation process.

What role can the active chlorine in E-PACl play in the $\mathrm{Al}_{13}$ speciation coagulation process? What factors can influence E-PACl during the removal of particles and OM? How can we furthest make use of the active chlorine in E-PACl to aid coagulation process? We have replied to the above questions in the present paper. We found the main water qualities affecting the E-PACl coagulation properties and clarified their corresponding mechanisms. Particular emphasis was paid on understanding the effect of active chlorine on the coagulation behavior for the removal of particulates and/or organic substances.

\section{Materials and methods}

\subsection{E-PACls preparation}

Two types of E-PACls were prepared by the new and original technique, respectively. When the anode potential was appropriately controlled, E-PACl $l_{1}$ containing active chlorine could be prepared in the electrochemical reactor with $\mathrm{Ti} / \mathrm{RuO}_{2}-\mathrm{TiO}_{2}$ anodes, Ti as cat- hodes, and $\mathrm{AlCl}_{3}$ aqueous solution as the electrolyte ${ }^{[12]}$. E-PACl was prepared by electrolysis process in the reactor with aluminum as anodes, iron as cathode, and $\mathrm{AlCl}_{3}$ aqueous solution as the electrolyte ${ }^{[16]}$.

\subsection{E-PACls characterization}

E-PACl $l_{1}$ and $\mathrm{E}-\mathrm{PACl}_{2}$ approximately have the same $\mathrm{Al}$ concentration $\left(\mathrm{Al}_{\mathrm{T}}\right)$, basicity $(\mathrm{B})$, and $\mathrm{Al}$ speciation characterization. The active chlorine in $\mathrm{E}^{-\mathrm{PACl}_{1}}$ is $5195.95 \mathrm{mg} / \mathrm{L}$ (Table 1). It was determined by spectrophotometric method using N, N-diethyl-1, 4-phenylenediamine (standard method of the State Environmental Protection Administration of China). Besides a small part of chlorine $\left(\mathrm{Cl}_{2}\right)$, hypochlorite $(\mathrm{HClO})$ is the main component of the active chlorine. ${ }^{27} \mathrm{Al}$ nuclear magnetic resonance (NMR) spectroscopy was used to characterize the $\mathrm{Al}$ species with ${ }^{27} \mathrm{Al}$ NMR spectra obtained on a VARIANUNITY INOVA (500 MHz) spectrometer. Details of the operating approaches and parameters of the apparatus can be found in ref. [16]. $B$ values were determined by titrimetric methods (Standard method of the chemical industry of China). The above characteristics are listed in Table 1.
Table 1 The properties of E-PACls

\begin{tabular}{|c|c|c|c|c|c|c|}
\hline E-PACl & $\begin{array}{c}\mathrm{Al}_{\mathrm{T}} \\
\left(\mathrm{mol} \cdot \mathrm{L}^{-1}\right)\end{array}$ & $B$ & $\begin{array}{c}\text { Active chlorine } \\
\left(\mathrm{mg} \cdot \mathrm{L}^{-1}\right)\end{array}$ & $\mathrm{Al}_{\mathrm{m}}(\%)$ & $\mathrm{Al}_{13}(\%)$ & $\mathrm{Al}_{\mathrm{u}}(\%)$ \\
\hline $\mathrm{E}-\mathrm{PACl}_{1}$ & 0.62 & 2.20 & 5195.95 & 2.5 & 79.8 & 16.7 \\
\hline E-PACl ${ }_{2}$ & 0.59 & 2.20 & 0 & 3 & 80.8 & 16.2 \\
\hline
\end{tabular}

\subsection{Preparation of the synthetic model water}

Kaolin (Xudong Chemical Reagent Company, Beijing, China) was used as the standard particles in the stock suspension, which was prepared in deionized water. The particle concentration was determined by weight analysis method. Humic acid (HA, Tianjin Chemical Reagent Company, China) was used as the model OM. The HA stock solution was prepared by adding HA into deionized water, and the $\mathrm{pH}$ was adjusted to 12. Afterward, this stock solution was stirred for $2 \mathrm{~h}$, and filtered for removing residual non-dissolved HA powder. Dissolved organic carbon (DOC) in the filtered solution was measured by a multi N/C 3000 TOC analyzer (Analytikjna, Germany).

Working water was prepared by adding $25 \mathrm{mg} / \mathrm{L}$ kaolin suspension and HA with different concentrations into the water that was made up of $50 \%$ deionized water and $50 \%$ tap water. The DOC of samples 1, 2, and 3 were 2,5 , and $10 \mathrm{mg} / \mathrm{L}$, respectively. The initial turbidity, hardness, and alkalinity of the three samples were $30 \mathrm{NTU}, 78 \mathrm{mg} \mathrm{CaCO}_{3} / \mathrm{L}$, and $58 \mathrm{mg} \mathrm{CaCO}_{3} / \mathrm{L}$, respectively.

\subsection{Jar tests}

Jar tests were performed using a Phipps and Bird six-paddle stirrer. The procedures consisted of rapid mixing (200 rpm) for $1 \mathrm{~min}$, slow mixing (30 rpm) for $15 \mathrm{~min}$, and settling for $30 \mathrm{~min}$. A small amount of sample was taken immediately to measure Zeta potential (Malvern, Zetasizer 2000, UK) after 1 min rapid mixing. For $30 \mathrm{~min}$ after settling, supernatants were collected to measure residual turbidity (RT) using an HACH $2100 \mathrm{~N}$ Turbidimeter. The filtrates were tested for DOC (Tekmar-Dohrman Co., Phoenix 8000, USA) and the $\mathrm{UV}_{254}$ (Hitachi, U-3010 spectrophotometer, Japan). A pre-determined amount of 0.2 or $0.05 \mathrm{~mol} / \mathrm{L}$ $\mathrm{NaOH}$ or $\mathrm{HCl}$ solution was added first into water samples to examine the influence of $\mathrm{pH}$ on particles and DOC removal. All reagents used were of analytical grade.

\section{Results and discussion}

\subsection{Effect of OM on coagulation}

The coagulation behavior of E-PACl ${ }_{1}$ and E-PACl ${ }_{2}$ 
was investigated for the three water samples. As shown in Figs. 1-3, with the increase of the coagulant dosages, the zeta potentials of particles gradually increased, and the residual turbidity and DOC gradually decreased. The removal of turbidity and DOC reached the maximum when the zeta potentials were close to the isoelectric point. Afterward, the zeta potentials were reversed and the removal of turbidity and DOC decreased due to the destabilization of particles in water samples. The good corresponding relationship between the zeta potentials and coagulation efficiency indicated that charge neutralization was mainly responsible for coagulation mechanism. Comparison of E-PACl ${ }_{1}$ and E-PACl ${ }_{2}$ indicated that the HA concentration in water samples significantly affected the performance of active chlorine in coagulation process.

The coagulation efficiency of E-PACl ${ }_{1}$ was higher than that of $\mathrm{E}-\mathrm{PACl}_{2}$ in water sample 1 (Fig. 1), where the active chlorine in $\mathrm{E}-\mathrm{PACl}_{1}$ aided the coagulation process. By contrast, the coagulation efficiency of E-PACl $l_{1}$ was lower than E-PACl $l_{2}$ in water sample 3 (Fig. 3), where the active chlorine in $\mathrm{E}-\mathrm{PACl}_{1}$ retarded coagulation process. In water sample 2 (Fig. 2), the
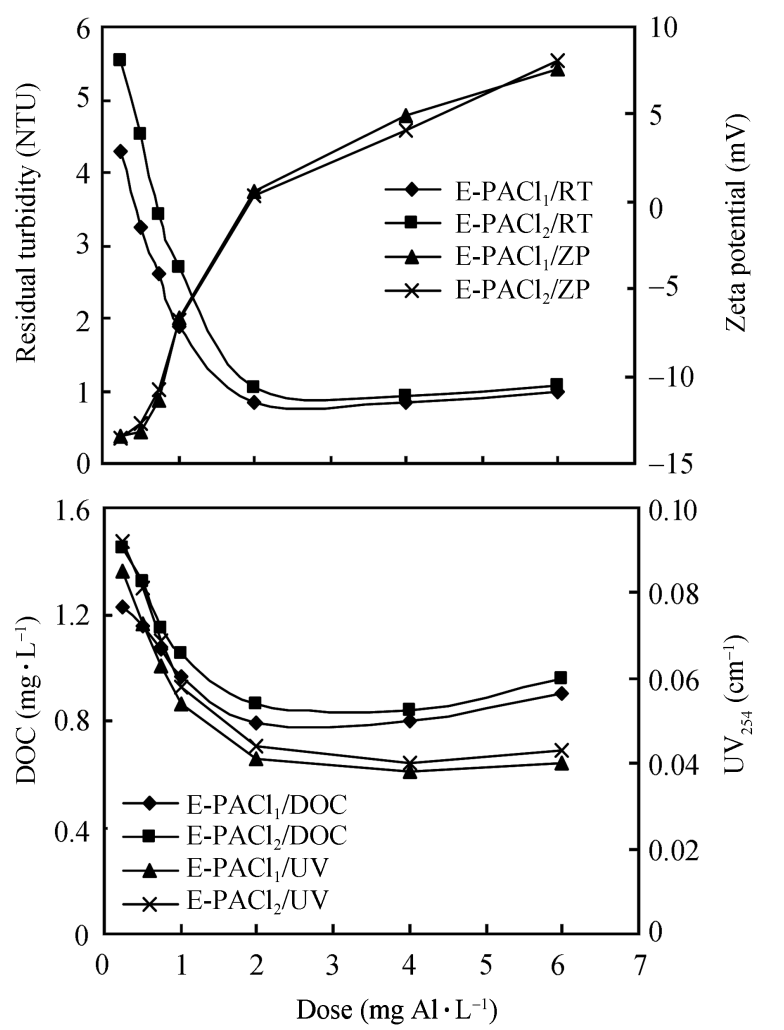

Fig. 1. Residual turbidity, zeta potential, DOC, and $\mathrm{UV}_{254}$ as a function of E-PACls dose (water sample 1).
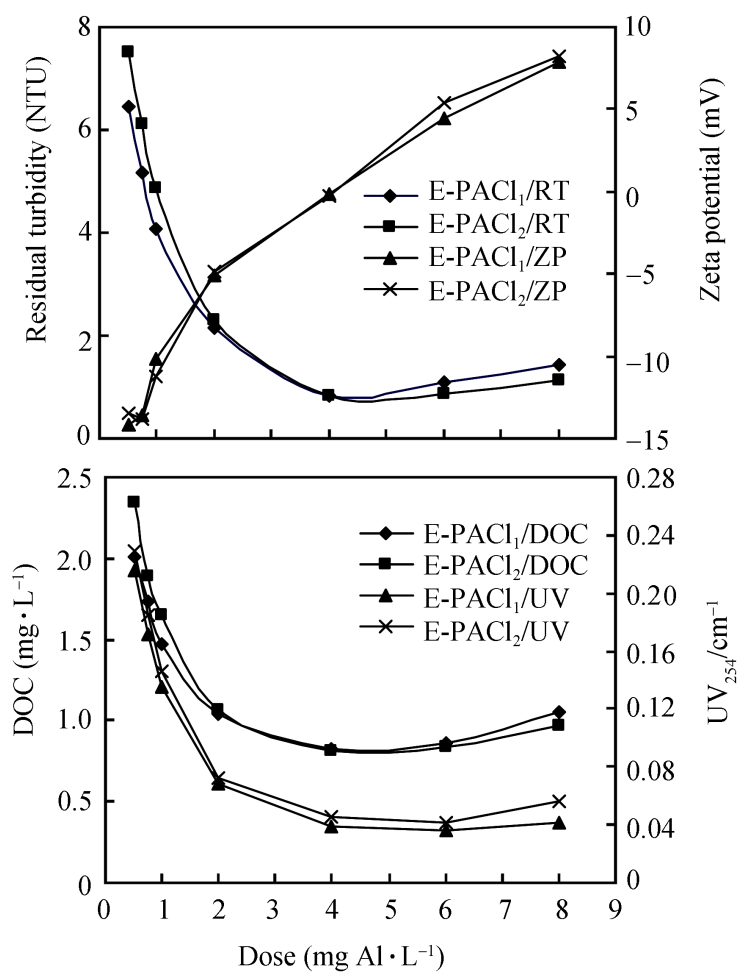

Fig. 2. Residual turbidity, zeta potential, DOC, and $\mathrm{UV}_{254}$ as a function of E-PACls dose (water sample 2).
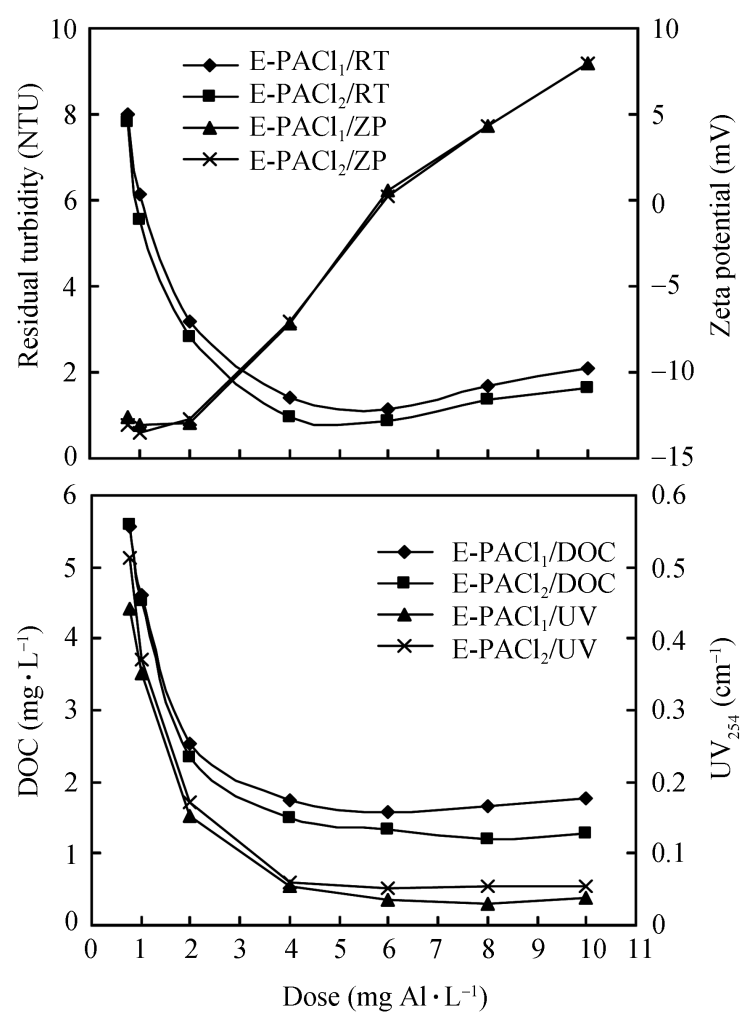

Fig. 3. Residual turbidity, zeta potential, DOC, and $\mathrm{UV}_{254}$ as a function of E-PACls dose (water sample 3). 
coagulation efficiency of E-PACl ${ }_{1}$ was higher than that of E-PACl ${ }_{2}$ at low dosages for example at $1 \mathrm{mg} \mathrm{Al} / \mathrm{L}$, where the active chlorine is $0.31 \mathrm{mg} / \mathrm{L}$, but the opposite results occurred at high dosages (e.g. at $6 \mathrm{mg} \mathrm{Al} / \mathrm{L}$, the active chlorine is $1.86 \mathrm{mg} / \mathrm{L}$ ). The water with relatively low HA concentration favored the assistant effect of active chlorine on coagulation process. In water sample 2 with medium content of OM ( $5 \mathrm{mg} / \mathrm{L})$, dosage would be a crucial factor to decide whether or not the active chlorine in E-PACl aided coagulation process, which was consistent with the results of Farvardin and Collins ${ }^{[27]}$ and Beker and O'Melia ${ }^{[28]}$.

HA could increase the colloidal stability of inorganic particles due to the adsorption of the organic on the mineral surface ${ }^{[29,30]}$. Also, higher molecular weight (MW) humics has a greater ability to stabilize the minerals particles than the lower MW counterparts ${ }^{[30,31]}$. The larger size fraction has less proton exchange capacity or, in fact, has a higher number of hydrophobic sites which can be adsorbed on the slight negatively charged surface of kaolinite particles better than the lower size fraction with a much proton exchange capacity. In water sample 3 (Fig. 3), although the efficiency of $\mathrm{E}-\mathrm{PACl}_{1}$ was lower than that of $\mathrm{E}-\mathrm{PACl}_{2}$ on the removal of turbidity and $\mathrm{DOC}$, the $\mathrm{UV}_{254}$ removal of $\mathrm{E}-\mathrm{PACl}_{1}$ was more effective than that of $\mathrm{E}-\mathrm{PACl}_{2}$ because larger MW HA was broken into smaller MW HA by the oxidation effect of the active chlorine in E-PACl ${ }_{1}$. These smaller compound are more negative and more polar $\mathrm{OM}$, and thus a higher coagulant dosage is needed to obtain the same DOC removal ${ }^{[32]}$. Generally, coagulant requirements are often set by the total organic carbon concentration (TOC) in a water source $^{[33]}$. For water containing low level of TOC, coagulant dosage is determined by the adsorbed OM. For water containing high level of TOC, coagulant dosage is determined by the dissolved OM. The above results were also confirmed in this study. There was a shift in the MW distribution of OM toward smaller DOC after doing E-PACl $1_{1}$. For water sample 1 with a lower HA concentration, the adsorbed HA was oxidized and broken up into smaller MW counterparts, which might benefit the coagulation because of a decreasing stability of particles. Thus, the active chlorine in $\mathrm{E}-\mathrm{PACl}_{1}$ could aid coagulation in water sample 1 . To the contrary, the active chlorine had an adverse effect on coagulation in water sample 3 because of the minishing MW distribu- tion of the dissolved HA.

Preoxidation may generate by-products in coagulation process. The active chlorine can break larger HA molecules into smaller and more polar compounds that are less likely to be removed by coagulation process. $\mathrm{Ca}^{2+}$ and $\mathrm{Mg}^{2+}$ can play a helpful role in the assistant effect of preoxidation on coagulation. Actually, these divalent metal ions may provide a buffer action to coagulation to resist the adverse effect of the by-products. The results of Dowbiggin and Singer ${ }^{1)}$ indicated that the divalent metal ions could form a bridge between the mineral particles and the polar chlorization intermediate by-products and thus these by-products along with the particles were removed by coagulation or, the divalent metal ions can form surface complex with these polar by-products thereby modifying the OM surface charge and forming a precipitates with Al coagulants. The similar results were also observed in water sample 2 (Fig. 2). At the low dosages, the amount of by-products was not enough to show the adverse effect on coagulation due to the buffer action of the divalent metal ions, thus the proper-dosing active chlorine benefited coagulation. At the high dosages, the divalent metal ions could not restrain the adverse effect due to the overfull by-products exceeding the buffer action capacity of the divalent metal ions, thus the overdosing active chlorine retarded coagulation.

\subsection{Effect of $\mathrm{Ca}^{2+}$ on coagulation}

As shown in Fig. 4, the coagulation efficiency of both E-PACl $l_{1}$ and $\mathrm{E}-\mathrm{PACl}_{2}$ was improved a lot after adding $2 \mathrm{mmol} / \mathrm{L} \mathrm{CaCl}_{2}$ into water sample 2 . In water sample 2 with the hardness of $278 \mathrm{mg} \mathrm{CaCO}_{3} / \mathrm{L}$, the optimum dosages were about $2.8 \mathrm{mg} / \mathrm{L}$, which was less than the optimum dosages (about $4 \mathrm{mg} / \mathrm{L}$ ) in the initial water sample 2. In addition, from comparison of Fig. 2 with Fig. 4 it can be found that the efficiency of E-PACl $l_{1}$ was higher than that of E-PACl $l_{2}$ even at the high dosages. The results indicated that the increase of hardness favored the coagulation process and was helpful to exerting the assistant effect of active chlorine in $\mathrm{E}-\mathrm{PACl}_{1}$ on coagulation.

The zeta potential of the particles in water sample 2 was transformed from -15.9 to $-13.6 \mathrm{mV}$ after adding $2 \mathrm{mmol} / \mathrm{L} \mathrm{CaCl}_{2}$ to water sample 2. With the in- crease of hardness, the stability of the particles in water sample 2 decreased, which favored the coagulation

1) Dowbiggin W B, Singer P C. Factors affecting the stability of particles in natural waters and their susceptibility to ozone-induced microflocculation, 1987, presented at the AWWA Conference, Kansas City, Mo. 

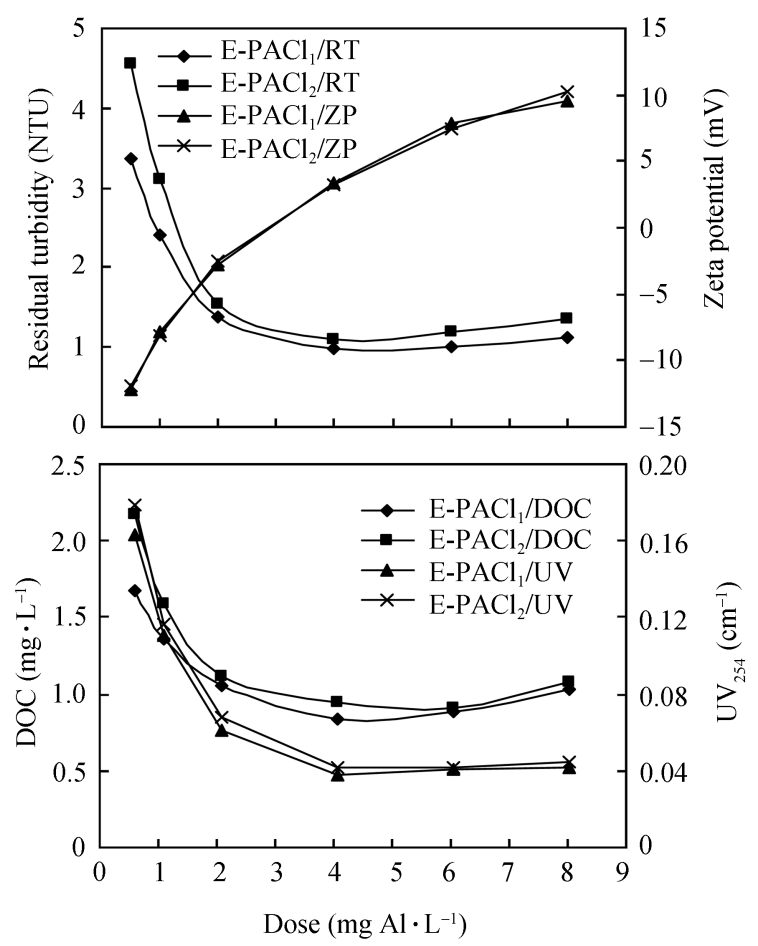

Fig. 4. Effect of $\mathrm{Ca}^{2+}$ on the E-PACls coagulation efficiency.

process. Moreover, the small polar OM could form complexs or be adsorbed onto mineral colloid surfaces through the $\mathrm{Ca}^{2+}$ bridge effect ${ }^{[34]}$, which also favored the coagulation process. Therefore, adding $\mathrm{Ca}^{2+}$ concentration in water not only enhanced the coagulation efficiency but also restrained the adverse effect of the polar chlorization intermediate by-products.

\subsection{Effect of $\mathrm{pH}$ on coagulation}

The effect of $\mathrm{pH}$ on coagulation was examined in water sample 1 and water sample 3, respectively. Figs. 5 and 6 show that both E-PACl ${ }_{1}$ and E-PACl ${ }_{2}$ had the highest removal efficiency of turbidity and DOC at about $\mathrm{pH}$ 6, which is the optimum $\mathrm{pH}$ region for $\mathrm{Al}$ coagulation process because of the lowest $\mathrm{Al}$ solubility here $^{[35]}$. In the $\mathrm{pH}$ area of $4-9$, the relative coagulation efficiency between E-PACl $l_{1}$ and E-PACl${ }_{2}$ was also influenced by the HA concentration, which were similar to those of Figs. 1 and 3. The differences of the two coagulants on the turbidity and DOC removal were much larger in the acidic area than in the alkaline region. It indicated that the active chlorine affected the coagulation process much more in the acidic area, i.e. the active chlorine had a greater positive or adverse effect on coagulation in the acidic area than in the alkaline region. $\mathrm{HClO}$ and $\mathrm{OCl}^{-}$are the effective components in the active chlorine. Among them, $\mathrm{HClO}$ is

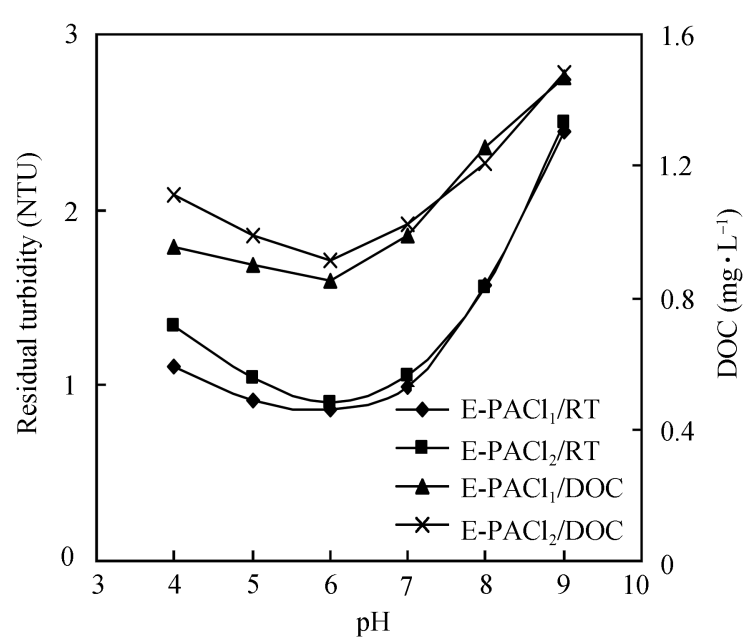

Fig. 5. Effect of $\mathrm{pH}$ on E-PACls coagulation efficiency (water sample 1).

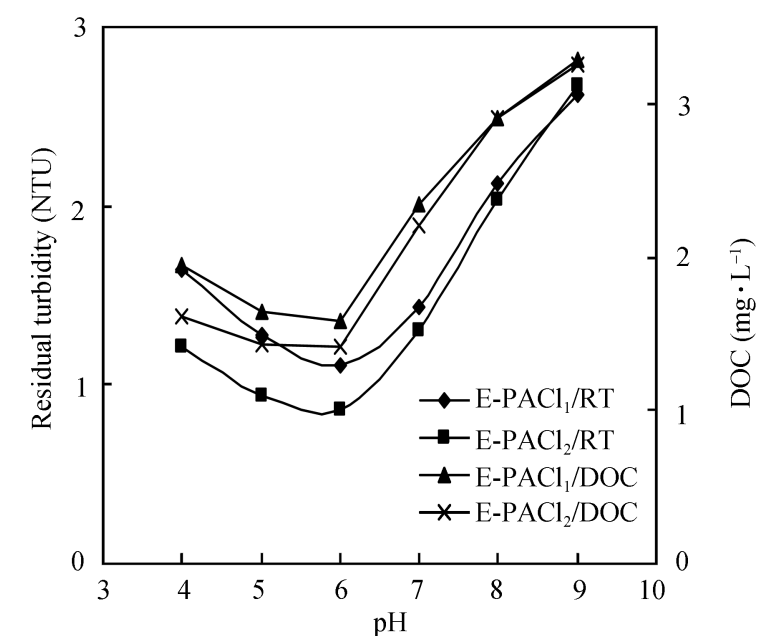

Fig. 6. Effect of $\mathrm{pH}$ on E-PACls coagulation efficiency(water sample 3).

more active in preoxidation and disinfection process. With the decreasing of $\mathrm{pH}$ value, the proportion of $\mathrm{HClO}$ in active chlorine gradually increases. This is the reason why the active chlorine in $\mathrm{E}-\mathrm{PACl}_{1}$ has a greater influence on coagulation process in the acidic region.

\section{Conclusion}

The active chlorine in E-PACl can significantly influence the coagulation behavior due to the active chlorine preoxidation, which can change the surface charge characteristic of $\mathrm{OM}$ in water. The preoxidation of the active chlorine could improve the E-PACl ${ }_{1}$ coagulation efficiency if the water possessed the characteristics of relatively low $\mathrm{OM}$ content $(2 \mathrm{mg} / \mathrm{L})$ and high hardness $\left(278 \mathrm{mg} \mathrm{CaCO}_{3} / \mathrm{L}\right)$. In the water with medium content of $\mathrm{OM}(5 \mathrm{mg} / \mathrm{L})$, dosage would be a crucial factor to decide whether or not the active chlorine in E-PACl aided coagulation process. Compared with alkaline 
condition, active chlorine would show a greater influence on coagulation process in acidic situation.

Acknowledgements This work was supported by the National Natural Science Foundation of China (Grant No. 50238050), and the National Science Fund for Distinguished Young Scholars (Grant No. 50225824).

\section{References}

1 Odegaard H, Fettig J, Ratnaweera H C. Coagulation with Prepolymerized Metal Salts, Chemical Water and Wastewater Treatment (ed. Hahn H H, Klute R). New York: Spinger-Verlag, 1990. $189-220$

2 Van Benschoten J E, Edzwald J K. Chemical aspects of coagulation using aluminum salts-I. Hydrolytic reactions of alum and polyaluminum chloride. Wat Res, 1990, 12: 1519-1526

3 Lind C. Reduce residuals with PACl coagulants. Public Works, 1994, Dec., 43

4 Sinha S, Yoon Y, Amy G, et al. Determining the effectiveness of conventional and alternative coagulants through effective characterization schemes. Chemosphere, 2004, 57: 1115-1122

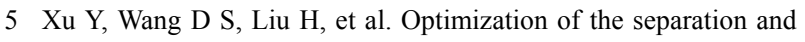
purification of $\mathrm{Al}_{13}$. Colloids and Surfaces A: Physicochem Eng Aspects, 2003, 231: 1-9

6 Wang S L, Wang M K, Tzou Y M. Effect of temperature on formation and transformation of hydrolytic aluminum in aqueous solutions. Colloids and Surfaces A: Physicochem Eng Aspects, 2003, 231: $143-157$

7 Gao B Y, Chu Y B, Yue Q Y, et al. Characterization and coagulation of a polyaluminum chloride (PAC) coagulant with high $\mathrm{Al}_{13}$ content. J Environ Manage, 2005, 76: 143-147

8 Buffle J, Parthasarathy N, Haerdi W. Importance of speciation methods in analytical control of water treatment processes with application to fluoride removal from wastewater. Wat Res, 1985, 19: $7-23$

9 Tang $\mathrm{H} \mathrm{X}$, Luan Z K. Features and mechanism for coagulation-flocculation processes of polyaluminum chloride. J Environ Sci, 1995, 7: 204-211

10 Tang H X. The new knowledge about the inorganic polymer flocculants. Industrial Water Treatment (In Chinese), 1997, 17(4): 1-5

11 Pasrthasarathy N, Buffle J. Study of polymeric aluminum (III) hydroxide solutions for application in waste water treatment: Properties of the polymer and optimal conditions preparation. Wat Res, 1985, 19: 25-36

$12 \mathrm{Lu} \mathrm{G} \mathrm{J,} \mathrm{Qu} \mathrm{J} \mathrm{H,} \mathrm{Tang} \mathrm{H} \mathrm{X.} \mathrm{The} \mathrm{electrochemical} \mathrm{production} \mathrm{of}$ highly effective polyaluminum chloride. Wat Res, 1999, 33(3): 807 $-813$

13 Liu H, Qu J, Zhang S, et al. Characteristics and formation of $\left[\mathrm{AlO}_{4} \mathrm{Al}_{12}(\mathrm{OH})_{24}\left(\mathrm{H}_{2} \mathrm{O}\right)_{12}\right]^{7+}$ in electrolysis process. Sci China Ser B-Chem, 2002, 45(5): 515-520

14 Liu H J, Qu J H, Hu C Z, et al. Characteristics of nanosized polyaluminum chloride coagulant prepared by electrolysis process. Colloids and Surfaces A: Physicochem Eng Aspects, 2003, 216: 139147

$15 \mathrm{Qu} \mathrm{J} \mathrm{H}$, Liu H J. Optimum conditions for $\mathrm{Al}_{13}$ polymer formation in $\mathrm{PACl}$ preparation by electrolysis process. Chemosphere, 2004,
55: $51-56$

$16 \mathrm{Hu} \mathrm{C} \mathrm{Z,} \mathrm{Liu} \mathrm{H} \mathrm{J,} \mathrm{Qu} \mathrm{J} \mathrm{H.} \mathrm{Preparation} \mathrm{and} \mathrm{characterization} \mathrm{of}$ polyaluminum chloride containing high content of $\mathrm{Al}_{13}$ and active chlorine. Colloids and Surfaces A: Physicochem Eng Aspects, 2005, 260(1-3): 109-117

17 Rice T G, Gomez-Taylor M. Occurrence of by-products of strong oxidants reacting with drinking water contaminants-Scope of the problem, Environ Hlth Persp, 1986, 69: 31-44

18 Haag W R, Hoigne J, Bager H. Improved ammonia oxidation by ozone in the presence of bromide ion during water treatment. Wat Res, 1984, 18: 1125-1128

19 Gilbert E. Biodegradability of ozonation products as a function of COD and DOC elimination by the example of humic acids. Wat Res, 1988, 22: 123-126

20 De Laat J, Dore M, Mallevialle J. Effects of preozonation on the adsorbability and the biodegradability of aquatic humic substances and on the performance of granular activated carbon filters. Wat Res, 1991, 25: 151-164

21 Amy G L, Tan L, Dacis M K. The effects of ozonation and activated carbon adsorption ono trihalomethane speciation. Wat Res, 1991, 25: 191-202

22 Richard Y. Importance of ozone in oxidation processes for treatment of potable water interference with other oxidants. Ozone Sci Engng, 1982, 4: 59-77

23 Richard Y, Brener L, Thebault P, et al. Influence of preozonation on clarification by floatation for drinking water treatment. Ozone Sci Engng, 1983, 5: 3-20

24 Jekel M R. The benefits of ozone treatment prior to flocculation process. Ozone Sci Engng, 1983, 5: 21-35

25 Reckhow D A, Singer P C. Removal of organic halide precursors by preozonation and alum coagulation. J Am Water Works Assoc, 1984, 76: $151-157$

26 Mathonnet S, Casellas C, Bablon G, et al. Impact of preozonation on the granulometric distribution of materials in suspension. Ozone Sci Engng, 1985, 7: 107-120

27 Farvardin M R, Collins A G. Preozonation as an aid in the coagulation of humic subatances-optimal preozoation dose. Wat Res, 1989, 23: $307-316$

28 Beker W C, O’Melia C R. Ozone, oxalic acid, and organic matter molecular weight-effects on coagulation. Ozone Sci Engng, 1996, 18: $311-324$

29 Gibbs R J. Effects of natural organic coatings and the coagulation of particles Envion Sci Technol, 1983, 17: 237-240

30 Jekel M R. The stabilization of dispersed mineral particles by adsorption of humic substances. Wat Res, 1986, 20: 1543-1554

31 Felix-Filho J A. The effects of aquatic humic substances and ozonation on the stability of particles. Ph. D. dissertation. University of North Carolina, Chaple Hill, N.C., USA

32 Edzwald J K. Coagulation in drinking water treatment: Particles, organics and coagulants. Wat Sci Tech, 1993, 27(11): 21-35

33 O'Melia C R, Becker W C, Au K K. Removal of humic substances by coagulation. Wat Sci Tech, 1999, 40(9): 47-54

34 Gaid K, Lemarchend D, Martin G, et al. Improving filter media (activated carbon) by oxidative pretreatment with ozone and persulfate. Ozone Sci Engng, 1983, 5: 113-127

35 Duan J, Gregory J. Coagulation by hydrolyzing metal salts. Advance in Colloid and Interface Science, 2003, 100-102: 475-502 